Note

\section{Identification of Cd-binding Peptides of Fission Yeast Schizosaccharomyces pombe by FRIT-FAB LC/MS}

\author{
Yutaka Kon-Ya, Etsuro Yoshimura, \\ Sunao Yamazaki and Shozo Toda
}

\author{
Department of Agricultural Chemistry, \\ Faculty of Agriculture, \\ The University of Tokyo, \\ I-1-I Yayoi, Bunkyo-ku, \\ Tokyo 113, Japan
}

Received April 18, 1990

Upon exposing fission yeast Schizosaccharomyces pombe to the $\mathrm{Cd}$ ion, $\mathrm{Cd}$-peptide complexes are induced. These complexes are composed of $\mathrm{Cd}$ ions, acid-labile sulfides, and of peptides named cadystin, whose structures have been elucidated as ( $\gamma$-Glu-Cys) $)_{n}$-Gly $(n=2$ and 3$) .{ }^{1)} \mathrm{A}$ family of these peptides with $n \geqq 2$ has also been shown to occur in plants, ${ }^{2-5)}$ and the name phytochelatin has been proposed for this kind of peptide. The peptides are considered to be involved in detoxification and homeostasis of heavy metal ions.

There are a few reports which have shown the occurrence of desglycyl peptides in Cd-peptide complexes. One of the $\mathrm{Cd}$-binding peptides purified from Zea mays has been proved to be lacking in Gly, being composed of Glu and Cys, by an amino acid analysis. ${ }^{6}$ In addition, based on a comparison of the amino acid composition between an acid hydrolysate and enzymatic digest of the $\mathrm{Cd}$-binding peptides from $S$. pombe and Candida glabrata, the presence of desglycyl peptides has been suggested. ${ }^{7,8}$

In this study, the peptides in a Cd-peptide complex of $S$. pombe were characterized by the recent coupling technique of high-performance liquid chromatography (HPLC) with fast atom bombardment mass spectrometry (Frit-FAB LC/MS ${ }^{9,10)}$ ).

S. pombe (IAM 4779) was cultivated in a medium containing $2 \%$ glucose, $2 \%$ tryptone, $1 \%$ yeast extract and $1 \mathrm{mM} \mathrm{CdCl}_{2}$ for 6 days. The cells were harvested and homogenized with quartz sand in buffer A $(25 \mathrm{~mm}$ Tris- $\mathrm{HCl}, \mathrm{pH} 7.5$, containing $50 \mathrm{mM} \mathrm{KCl}$ and $1 \mu \mathrm{M} \mathrm{CdCl}$ ). The homogenate was centrifuged at $15,000 \times g$ for $30 \mathrm{~min}$ at $4^{\circ} \mathrm{C}$, and the supernatant was applied to a Sephadex G-50 column $(16 \times 650 \mathrm{~mm}$, Pharmacia $)$ with buffer A. Cadmium and sulfhydryl groups in the fractions were measured by atomic absorption spectrometry and by the method of Ellman, ${ }^{11)}$ respectively. The $\mathrm{Cd}$ and sulfhydrylcontaining fractions (elution volume from 70 to $100 \mathrm{ml}$ ) were collected, loaded into a QAE-Sephadex A-25 column
$(16 \times 140 \mathrm{~mm})$ that had been equilibrated with $25 \mathrm{~mm}$ Tris- $\mathrm{HCl}$ at $\mathrm{pH} 7.5$, and chromatographed by a linear gradient of $0-1 \mathrm{M} \mathrm{NaCl}$ in the same buffer as that used for the equilibration. The fractions rich in $\mathrm{Cd}$ and sulfhydryl groups, which appeared at around $0.6 \mathrm{M} \mathrm{NaCl}$, were collected, desalted by a Sephadex G-15 column and lyophilized. The dried material was dissolved in $0.1 \%$ trifluoroacetic acid (TFA) and subjected to FRIT-FAB LC/MS (JEOL model JMS-AX505W) with a $4.6 \mathrm{~mm} \times$ $15 \mathrm{~cm}$ ODS column (Nomura Kagaku Co.). A combination of isocratic elution $(0.1 \%$ TFA-acetonitrile $=$ $93: 7$ for $5 \mathrm{~min})$ and successive linear gradient elution $(0.1 \%$ TFA-acetonitrile $=93: 7$ to $80: 20$ in $15 \mathrm{~min}$ ) was employed, in which the flow rate of the eluent was 1.0 $\mathrm{ml} / \mathrm{min}$. The eluate was monitored by absorption at 210 $\mathrm{nm}$, and a $10 \%$ glycerol solution was added to it just prior to its introduction to the MS spectrometer.

As shown in Fig. 1(A), the HPLC chromatogram gave four apparent peaks designated as P-I to P-4, apart from that appearing at the void volume. Mass spectra of the peaks are shown in Fig. 1(B) to (E), respectively. In Fig. l(B), a base peak appeared at $m / z 540$, which corresponds to the mass number of $\left[(\gamma-\mathrm{Glu}-\mathrm{Cys})_{2}-\mathrm{Gly}+\mathrm{H}\right]^{+}$. The mass numbers expected to have arisen from the fragmentation of $(\gamma \text {-Glu-Cys })_{2}$-Gly are shown in Fig. 2 , in which the ions observed in the spectrum are marked by asterisks. The nomenclature in Ref. 12 is used for of the fragment ions in the spectrum of ( $\gamma$-Glu-Cys) $)_{2}$-Gly. More than a half of the $\mathrm{N}$-terminal ions and only the $\mathrm{Y}^{\prime \prime}$-series of the $\mathrm{C}$-terminal ions can be seen in the spectrum. P-1 was, therefore, assigned as ( $y$-Glu-Cys) ${ }_{2}$-Gly, which many workers have isolated from this fungus.

The mas spectrum of P-2 showed a base peak at $\mathrm{m} / \mathrm{z}$ 483 , which corresponds to a substance lacking in Gly from $(\gamma \text {-Glu-Cys })_{2}$-Gly. In this mass spectrum, the N-terminal fragment ions which appeared in the P-I spectrum were also observed. However, the peaks at $m / z 179$ and 308 , the C-terminal fragment ions from P-1, did not occur, and peaks at $m / z 122$ and 251 emerged with minor intensity, which differ by a 57 mass unit from the C-terminal ions of P-1. These data supported P-2 being assigned to the peptide of $(\gamma \text {-Gly-Cys })_{2}$. In a similar manner, P-3 and P4 could be assigned to $(\gamma-\text { Glu-Cys })_{3}$-Gly and $(\gamma$-GluCys) ${ }_{3}$, respectively.

The levels of the desglycyl peptides depended on the culturing period. They were not detected in the earlier stage of culture, while they increased with culturing period (data not shown). The synthetic pathway for the desglycyl peptides has not been clarified. According to the report ${ }^{13)}$ on the synthesis of the peptides, $(\gamma \text {-Glu-Cys })_{2}$-Gly was formed by transpeptidation of the $\gamma$-Glu-Cys moiety of glutathione to another glutathione, and ( $\gamma$-Glu-Cys) - -Gly with $n \geqq 3$ was also successively formed by a similar transpeptidation. For the synthesis of the desglycyl peptides, there are two possible mechanisms. One is that the $\gamma$-Glu-Cys moiety of glutathione is transferred to the $\gamma$-Glu-Cys moleculle that is the precursor of glutathione. 

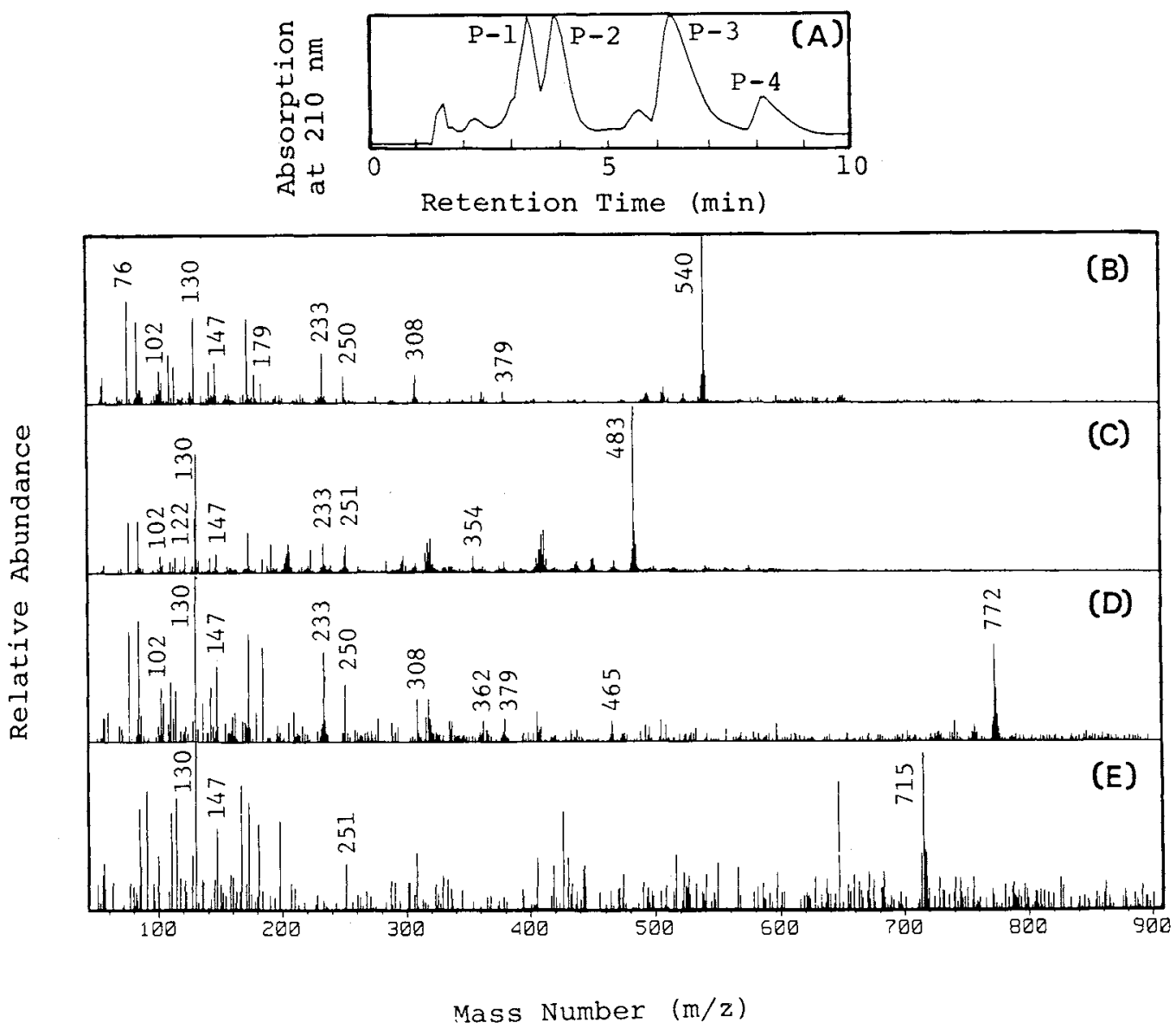

Fig. 1. FRIT-FAB LC/MS Analysis of the Cd-Binding Complex in S. pombe.

(A): Chromatogram monitored by the absorption at $210 \mathrm{~nm}$. (B), (C), (D) and (E): Mass spectra of P-1, P-2, $\mathrm{P}-3$ and $\mathrm{P}-4$, respectively.

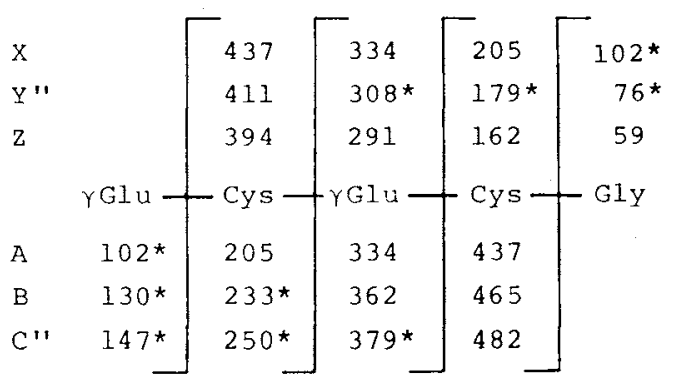

Fig. 2. Possible Fragment Ions from the Peptide $(\gamma$ Glu-Cys) $)_{2}$-Gly.

The ions observed in the mass spectrum shown in Fig. 1 (B) are marked by an asterisk. In peptide $R_{N}$ CONHR $R_{C}$, where $R_{N}$ and $R_{C}$ are the $N$ - and $C$-terminal moieties, respectively, the fragment ions are represented as follows: $\mathrm{A}, \quad \mathrm{R}_{\mathrm{N}}^{+} ; \mathrm{B}, \quad \mathrm{R}_{\mathrm{N}} \mathrm{CO}^{+} ; \mathrm{C}^{\prime \prime}, \quad\left[\mathrm{R}_{\mathrm{N}} \mathrm{CONH}_{2}+\mathrm{H}\right]^{+} ; \mathrm{X}$, CONHR ${ }_{\mathrm{C}}^{+} ; \mathrm{Y}^{\prime \prime},\left[\mathrm{H}_{2} \mathrm{NR}_{\mathrm{C}}+\mathrm{H}\right]^{+} ; \mathrm{Z}, \mathrm{R}_{\mathrm{C}}{ }^{+}$. The number of prime indicates that of the hydrogen atom transferred.
The other is that Gly is released from the formed peptides by hydrolytic cleavage by carboxypeptidase. At present, it is unclear which process acts. These desglycyl peptides could form heavy metal complexes, ${ }^{7}$ so that they would be considered to function as a detoxification substance for the metals together with the peptides, $(\gamma \text {-Glu-Cys })_{n}$-Gly $(n \geqq 2)$. A further study is, therefore, needed to elucidate the synthetic mechanisms.

Acknowledgments. We thank Dr. K. Matsuura and Dr. T. Aoyama of JEOL Ltd. for their measurement of the mass spectra.

\section{References}

1) N. Kondo, K. Imai, M. Isobe, T. Goto, A. Murasugi, C. Wada-Nakagawa and Y. Hayashi, Tetrahedron Lett., 25, 3869 (1984).

2) E Grill, E.-L. Winnacker and M. H. Zenk, Science, 230, 674 (1985). 
3) E. Grill, E.-L. Winnacker and M. H. Zenk, FEBS. Lett., 197, 115 (1986)

4) E. Grill, E.-L. Winnacker and M. H. Zenk, Proc. Natl. Acad. Sci. U.S.A., 84, 439 (1987).

5) P. J. Jackson, C. J. Unkefer, J. A. Doolen, K. Watt and N. J. Robinson, Proc. Natl. Acad. Sci. U.S.A., 84, 6619 (1987).

6) W. R. Bernhard and J. H. R. Kägi, in "Metallothionein 2," ed. by J. H. R. Kägi and Y. Kojima, Birkhäuser Verlag, Basel, 1986, p. 309.

7) R. K. Mehra and D. R. Winge, Arch. Biochem. Biophys., 265, 381 (1988).
8) R. K. Mehra, E. B. Tarbet, W. R. Gray and D. R. Winge, Proc. Natl. Acad. Sci. U.S.A., 85, 8815(1988).

9) Y.Ito, T. Takeuchi, D. Ishii, M. Goto and T. Mizuno, J. Chromatogr., 358, 201 (1986).

10) K. Kamei, K. Kitahara, A. Momose, K. Matsuura and H. Yuki, Mass Spectrometry, 36, 115 (1988).

11) G. L. Ellman, Arch. Biochem. Biophys., 82, 70 (1959).

12) P. Roepstorff and J. Fohlman, Biomed. Mass. Spec., 11, 601 (1984).

13) E. Grill, S. Loeffler, E.-L. Winnacker and M. H. Zenk, Proc. Natl. Acad.Sci. U.S.A., 86, 6838 (1989). 